\title{
3D PRINTING AND BEYOND: INTELLECTUAL PROPERTY AND REGULATION. MENDIS, D.; LEMLEY, M.; RIMMER, M. (EDS.).
} by

PAVEL LOUTOCKÝ**

Mendis, D.; Lemley, M.; Rimmer, M. (eds.). (2018) 3D Printing and Beyond: Intellectual Property and Regulation. Cheltenham: Edward Elgar Publishing, $432 p$.

Even though the technology connected with 3D printing provides new development, it cannot be considered as anything purely original in the area of intellectual property law; ${ }^{1}$ it just brings more possibilities and makes creating of any imaginable shapes easier and more accessible.

"3D printing [has] two essential characteristics [...]: It radically reduces the cost of production and distribution of things, and it separates informational content of those things (the design) from their manufacture. [...] The role of IP in such a world is both controverted and critically important." ${ }^{2}$

Even if the technology itself in this area did not bring anything purely new, the legal point of view is constantly struggling with it, it hardly finds

\footnotetext{
The review was written within the project MUNI/A/1006/2018 (Law and Technology VII).

** loutocky@law.muni.cz, legal specialist and post doc at the Institute of Law and Technology of the Faculty of Law, Masaryk University, Brno, the Czech Republic. He is also Head of the Legal Department of the Technology Transfer Office of Masaryk University. He also works as a lawyer at the Centre for Excellence for Cybercrime, Cyber Security and Critical Information Infrastructure Protection at Masaryk University.

1 For the overview of some relevant literature and description of the history of regulation and possible approaches see e.g. Tran, J. L. (2015) The Law and 3D Printing. The John Marshall Journal of Information Technology \& Privacy Law, 31 (4), p. 510 et seq.

2 See p. 31 of the book.
} 
proper legal analogies ${ }^{3}$ and moreover, there is a constant lack of decent literature in this area despite the fact that we have been already talking about this topic for a few decades. ${ }^{4}$

This improper situation and also the important role of IP rights was understood also by the authors of the book $3 D$ Printing and Beyond: Intellectual Property and Regulation, who in 2015 set out to create a collection focused on the issue of $3 \mathrm{D}$ printing with the main task to think about the technological challenges associated with this area in the long term horizon and to change the rigid approach that is still evident. ${ }^{5}$ The book was published in 2019 by Edward Elgar Publishing.

The need for a quick change of the approach to 3D printing and revision of legislation especially in the area of IP rights has been understood in various countries. Whole structure of the book is focused only on three territories - the United Kingdom, the United States of America and Australia. The editors justify the choice of those three territories in the introductory chapter by the fact, that (i) these three selected countries are active in development of 3D printing and they position themselves as world leaders, ${ }^{6}$ (ii) these countries are supporting progressive IP policy reforms in the legislation of 3D printing and additive manufacturing technologies and (iii) these countries share the common law tradition. ${ }^{7}$ Even though such an explanation is understandable, the choice of those three countries and the argument on it does not fully stand in our opinion. It seems more that these three territories have been selected mainly based on the fact, that the editors (and overall the authors) have somehow been related to this area. The editors have unfortunately did not consider deeper

\footnotetext{
3 The importance of legal revision in the area of 3D printing was highlighted recently by the European Parliament in Draft report on three-dimensional printing, a challenge in the fields of intellectual property rights and civil liability in the beginning of year 2018 (see Committee on Legal Affairs. European Parliament. (2018) Draft report on three-dimensional printing, a challenge in the fields of intellectual property rights and civil liability (2017/2007(INI)). [online] Available from: http://www.europarl.europa.eu/meetdocs /2014_2019/plmrep/COMMITTEES/JURI/PR/2018/06-20/1146633EN.pdf [Accessed 9 May 2019]).

4 Yanisky-Ravid and Kwan are arguing that legal environment was and still is being caught totally unprepared. This doesn't by their opinion mean that 3D printing should bring new concepts, some legal instruments however must adapt to new situations (see YaniskyRavid, S. and Kwan, K. S. (2017) 3D Printing the Road Ahead: The Digitization of Products When Public Safety Meets Intellectual Property Rights - A New Model. Cardozo Law Review, 38 (3), pp. 921 and 936 et seq).

5 See p. 2 of the book.

6 Between the other countries the editors mention Germany, Japan, South Korea or China (see p. 8 of the book).

7 See p. 8 of the book.
} 
explanations which are contradictory to the mentioning that the book offers holistic insight into IP implications of 3D printing. ${ }^{8}$ This however only indicates that the methodology of the choice was not well chosen or justified, but it cannot in itself indicate that the publication is of poor quality. On the contrary. From a general point of view, a relatively careful selection of authors and areas of their interest is clearly visible in the book. Those are described later.

Before the book starts to assess the particularities in the above-mentioned territories, Lemley introduces the main impact of 3D printing IP in a world without scarcity. The main intent of Lemley is to introduce the fact that

"3D printing exacerbates the public goods problem of IP theory by making it much cheaper to imitate than to create."

He stresses out that similar arguments are used when talking about the impact of the Internet on IP law. ${ }^{10}$ What we then see as something additional in $3 \mathrm{D}$ printing is the material aspect of the technology. Lemley then broadly concludes on the topic of scarcity, that there is a fight of IP owners for scarcity (limited amount of products), which will be in his opinion lost. He stresses out that IP owner's loss is (mostly) innovation's success. ${ }^{11}$ He thus believes that legal regulation should be more open and not protective only towards the IP owners. This chapter thus serves as a theoretical introduction of what 3D printing brings to the classical concepts of IP right. The author correctly identified the similarities to the issues we are dealing with the Internet regulation, thus it is logical outcome.

The first part of the book focuses on the issues of 3D printing connected to the territory of the United Kingdom. The area is opened by the article 'Back to the future'? From engravings to 3D printing - implications for UK copyright law, which focuses on the history of regulation on 3D printing in the UK and its practical implications. Mendis sees the biggest issues in the question if new and innovative regulation is really needed. This question is not clearly answered. However the author states that

\footnotetext{
Ibid.

See p. 39 of the book.

10 Ibid.

11 See p. 50 of the book.
} 
clarification of the legal mechanisms, better enforcement and a new approach to business models is the key to support further development of 3D printing. ${ }^{12}$ Margoni in the article Design rights and $3 D$ printing in UK: balancing innovation and creativity in a (dis)harmonised and fragmented legal framework specifies some reforms of legal approaches and stresses the necessity to establish a better relationship between copyright and design protection. Following two articles Digital trade mark infringement and 3D printing implications: what does the future hold? by Hong and Bradshaw and $3 D$ printing and patent law - a UK perspective: apt and ready? by Mimler are both analysing the readiness of industrial protection mechanisms in connection with 3D printing. While the authors of the first of these articles argue in favour of the existing regulation, which they believe is ready for the advancement of modern technology, ${ }^{13}$ the situation is rather different in the case of patent law. Mimler highlights the necessity to protect the role of intermediaries offering space to share the blueprints as they seem to be beneficiary to the society. He is also quite sceptical about massive patent infringement by regular users as the technological possibilities of 3D printing are not that precise to copy often complicated inventions protected by patent. ${ }^{14}$ The last article in the first chapter Transformative technologies and responsive legal scholarship by Brownsword highlights the important role of pragmatic approach while regulating issues of 3D printing. This article is rather theoretical and basically follows the methodological approach which is generally used when dealing with legal regulation of modern technologies. He thus also mentions the need for involvement of smart rules and approach based on the empirical experience, not only on the basis of impression. ${ }^{15}$

The second part is focused on the legal issues of 3D printing in the USA. The first article $3 D$ printing and US copyright law: implications for software, enforcement and business strategies by Mennel and Vacca identifies main issues in copyright law focused mainly on software and law enforcement. They argue, that when applying legal regulation, we can use some analogies, but the biggest challenge is, in fact, that the area brings whole new opportunities to product manufacturing and design business, consumers,

\footnotetext{
${ }^{12}$ See pp. 76-77 of the book.

13 The authors are mainly focusing on practical process of 3D printing which is realized through vector CAD files.

14 See p. 130 et seq. of the book.

15 See p. 152 et seq. of the book.
} 
designers, etc. Such a relatively simple statement is however supported by some practical examples of how the transformative power of modern technologies (and 3D printing) works together with classical legal mechanisms (such as enforcement issues in connection with Digital Millennium Copyright Act or DRM protection).$^{16}$ Following two articles Integrating a classical tool for a modern challenge: US design patents implication for 3D printing by Ferrill, MacKichan, McKinley and Horn and Remedies for digital patent infringement: a perspective from the USA by Holbrook are both focused on patent protection and design patents. The authors of the first article argue for practical applicability of design patents in case of protecting graphical user interface and predict the rise of such instrument in the protection of the rights. ${ }^{17}$ In the second article focused on patent infringement the author tries to provide the first effort at predicting how the remedies work in this area and states that

"when digital downloading's impact on the copyright system is a harbinger of what the patent system will face, the difference between the two regimes means that the patent system will struggle even more to combat digital infringement". ${ }^{18}$

Desai in his article How 3D printing disrupts trade dress protection then deals with the dress protection and points out that the ability to make something easy with $3 \mathrm{D}$ printing is not the same as guaranteeing that this good is made with safe materials - so the companies are by their mass production guaranteeing the quality and the source. 3D printing thus pushes (and will push) companies to improve the overall quality of mass-produced goods. ${ }^{19}$ The last contribution to the chapter by the same author deals with the issue of How democratized production challenges society's ability to regulate. He concludes that

"democratizing technology can unleash great benefits while also removing the chance of meaningful management and regulation by society". ${ }^{20}$

${ }_{16}$ See p. 170 et seq. of the book.

17 See p. 199 et seq. of the book.

18 See p. 232 et seq. of the book.

19 See p. 214 et seq. of the book.

${ }^{20}$ See p. 250 et seq. of the book. 
This, however, cannot be taken as negative effect leading to overregulation and then to suffocation of newly developing technology; the right balance is needed. Desai is however not indicating the level of regulation. Thus, we are left without the answer where the balance is needed - this is, however, unfortunately, the outcome of many academic works which are dealing with the issues of regulation of modern technologies and the enforcement.

The last big chapter is focused on the territory of Australia and follows a similar pattern as in previously introduced chapters. This chapter is, similarly to the previous chapters, opened with general article Makers Empire: Australian copyright law, 3D printing and the 'Ideas Boom' by Rimmer. He stresses out that

"Australia's copyright exceptions for libraries, galleries, archives, and museums are anachronistic and ill-adapted for an age of $3 D$ printing, ${ }^{\prime 21}$

thus there is only limited interest in investments to $3 \mathrm{D}$ printing. ${ }^{22}$ This conclusion is also supported by Berger in the article ,Substantial similarity" under Australian design law in connection with design regulation. He also adds that even though the rise of 3D printing technology has some disruptive impacts on the authors/producers, the positive impacts must be assessed more carefully. ${ }^{23}$ Scardamaglia in connection with trademark protection relatively simply concludes that it is probably more important

"to pause and reflect on some more troubling aspects of trade mark law that have long warranted further attention, but have not yet received it..."24

in the article Trade mark controversies in $3 D$ printing. We have to agree with her on the point that keeping the pragmatic approach and to mute hysteric overregulation $^{25}$ is the key for this industry. Basically, the same idea is followed more generally with concluding article of the chapter called Don't believe the hype? Recent 3D printing developments for law and society by Daly, where she stresses that in the current state $3 \mathrm{D}$ printing is not prevalent enough yet to be disruptive for law or for society (despite the potential). ${ }^{26}$ As each chapter of the book is trying to offer the place to similar areas

\footnotetext{
21 See p. 293 et seq. of the book.

22 Ibid.

23 See p. 302 et seq. of the book.

${ }^{24}$ See p. 324 of the book.

25 Ibid.

${ }^{26}$ See p. 359 et seq. of the book.
} 
of the interest, Nielsen and Nicol are focusing on patent protection in the article The reform challenge: Australian patent law and the emergence of $3 D$ printing. Even though they are supporting legislative changes in the area which were made by Australian legislators, ${ }^{27}$ they are pointing out that it was not done conceptually, and the main problem is that the legislators did not focus on infringement of patent law. This thus leads to problematic applicability of described legal regime and difficult (if even possible) enforcement. ${ }^{28}$

It is apparent from the above-described that the individual chapters within the three mentioned territories do not overlap as much. The authors rather focused on the topics that were more suitable to them than to follow general pattern of the book. Thus, the areas specifically examined in some territory are not always covered in the other, which leads to some fragmentation of the book as a whole and overall impression that the book does not "hold together" (the book is giving the impression that it is more of assemblage of essays). Thus, the reader's orientation in the text can be in some parts more difficult. However, the contributions themselves are of sufficient quality, so if the reader is looking for information about 3D printing in a given territory, the book will offer him a nice overview. This is also supported by the fact that the articles were not written only by academics but also by practising lawyers.

The whole book is after three big parts enclosed with the article from the editors called The future of printcrime: intellectual property, innovation law, and $3 D$ printing. They are mainly concluding previous findings and add valuable chapter on future research. Unfortunately, they are however focusing only on new areas where 3D printing can be used, such as food printing, robot law, medicine, space missions (and many other areas) without any deeper focus on legal issues (which is somewhat the anticipation from the legal text). The last chapter more focuses on the possibility of technology and not the possibility of legal regulation, which would be more expected by the reader. ${ }^{29}$ The editors are only concluding that it is always necessary to balance legal regulation with a possible limitation of the technology, which is however nothing new. We think that it is not the era of assessment of legal regulation in the area of 3D

27 See more on the legislation at p. 340 et seq. of the book.

28 See p. 343 et seq. of the book.

29 See p. 386 et seq. of the book. 
at the moment (in our opinion general assessment has been done sufficiently for last decade), but we should move to the point of more exact proposals and improvements of the legal framework related to 3D printing. This hesitant approach to propose anything "revolutionary" is apparent from the whole book and we see it as the wasted potential of the publication. This should however not imply that the book itself does not bring anything new - what we are trying to say is that it should have possibly brought a bit more especially in terms of more specific proposals how to contribute to appropriate regulation of the area of $3 \mathrm{D}$ printing.

\section{LIST OF REFERENCES}

[1] Draft report on three-dimensional printing, a challenge in the fields of intellectual property rights and civil liability in the beginning of year 2018. Committee on Legal Affairs. European Parliament. (2018) Draft report on three-dimensional printing, a challenge in the fields of intellectual property rights and civil liability (2017/2007(INI)). [online] Available from: http://www.europarl.europa.eu/meetdocs/2014_2019/plmrep/ COMMITTEES/JURI/PR/2018/06-20/1146633EN.pdf [Accessed 9 May 2019].

[2] Tran, J. L. (2015) The Law and 3D Printing. The John Marshall Journal of Information Technology \& Privacy Law, 31 (4).

[3] Yanisky-Ravid, S. and Kwan, K. S. (2017) 3D Printing the Road Ahead: The Digitization of Products When Public Safety Meets Intellectual Property Rights - A New Model. Cardozo Law Review, 38 (3). 